\title{
ANEURYSMAL BONE CYSTS
}

\section{Review of Twelve Cases}

\section{J. R. Clough and C. H. G. Price, Bristol, England}

This paper gives an account of aneurysmal bone cysts recorded in the Bristol Bone Tumour Register. Since Jaffe and Lichtenstein in 1942 suggested the name aneurysmal bone cyst, to draw attention to the characteristic radiological picture of a "blow out" of the bone and to its cystic nature, it has come to be widely accepted as a definite clinico-pathological entity. Diagnosis in a case showing typical features usually presents little difficulty. When there is some variation in these features, confusion with other lesions, particularly giant-cell tumour, unicameral bone cyst, haemangioma of bone, and even osteosarcoma may occur.

The lesion is an uncommon one and personal experience is obviously limited. A number of cases have been reported from abroad (Jaffe 1950; Lichtenstein 1950, 1953, 1957; Dahlin, Besse, Pugh and Ghormley 1955; Cruz and Coley 1956) but few from this country (Barnes 1956, Taylor 1956, Crabbe 1962). The features of twelve new cases are outlined in Table I.

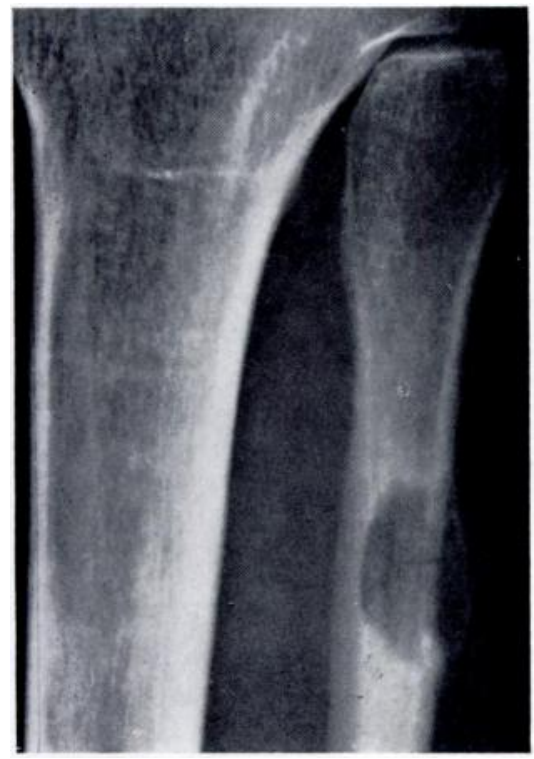

FIG. 1

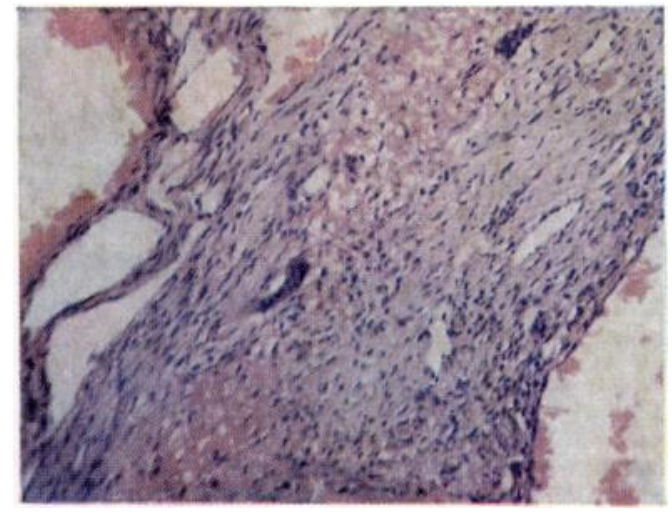

FIG. 2

Figs. 1 AND 2

Case 12. Figure 1-A faintly visible fracture through an eccentrically placed aneurysmal bone cyst in the diaphysis of the fibula. Figure 2-Showing the typical features of aneurysmal bone cyst. (Haematoxylin and eosin, $\times 100$.)

\section{CLINICAL FEATURES}

Age-Aneurysmal bone cysts are usually found in the immature skeleton; nine of those reported here were in children and young adolescents. Of the three found in the mature skeleton two were in patients of twenty-two and seventeen (Cases 1 and 11), and it is possible that these may have arisen before skeletal growth had stopped. In the third adult (Case 12), a woman of fifty-six, her age argued strongly against the lesion being an aneurysmal bone cyst, but the radiological appearance (Fig. 1) and the operative and histological features (Fig. 2) were typical.

Sex distribution-In other series the sex incidence has been more or less equal. In this report there were seven males and five females. 
Site-Aneurysmal bone cysts have been found in most bones of the skeleton, but Jaffe (1958) states that over three-quarters occur in the spine and long bones. In our cases nine were in long bones, two in the spine and one in a short tubular bone.

Symptoms and signs-Pain and swelling were the two main symptoms. Six patients presented with pain from a pathological fracture or some lesser injury. Pain was not usually a feature of the uncomplicated growth of the cyst and when it did occur it was not severe. Four patients had noticed only a painless swelling. Apart from local swelling and sometimes tenderness, there was little else abnormal in these cases. In one patient the movements of the hip were limited. In neither of the spinal cases was there any interference with spinal cord function.

\section{RADIOLOGICAL FEATURES}

These varied. In some they were typical but in others they were less characteristic. The typical features are of a well circumscribed, rarefied area having a finely trabeculated appearance. Expansion is marked and the overlying cortex is thin or absent, the lesion being bounded by a thin, sometimes barely detectable, layer of subperiosteal new bone. The intraosseous part

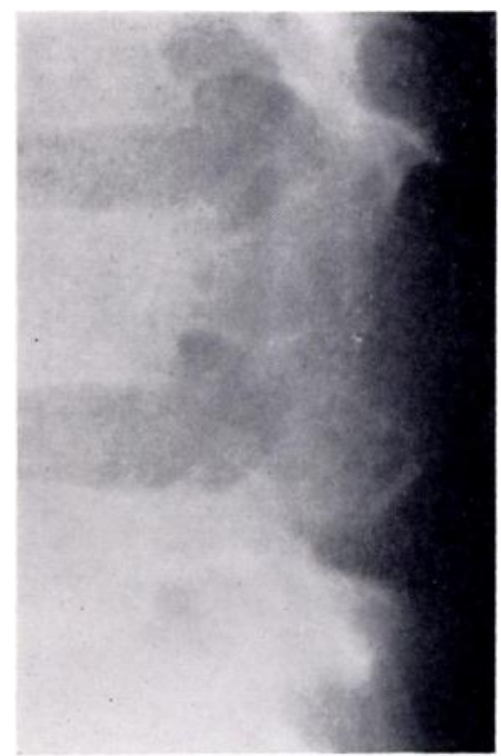

FIG. 3

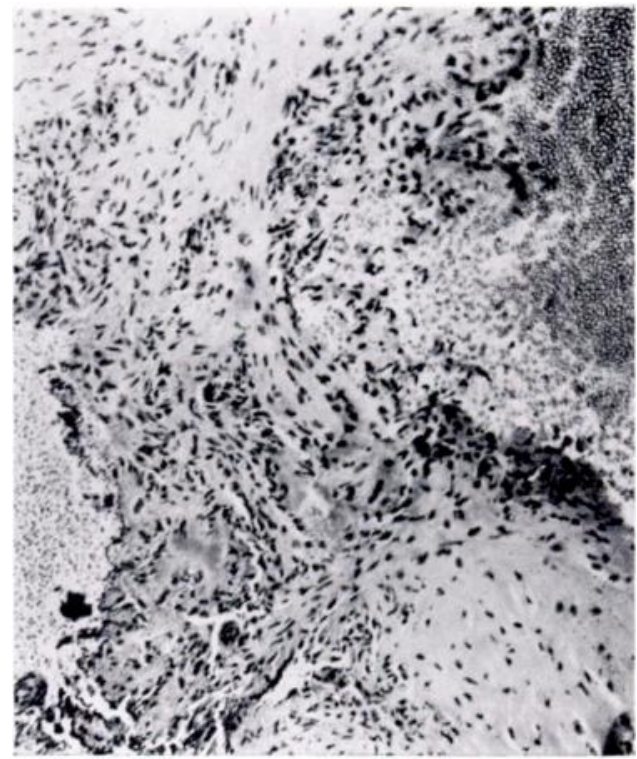

Fig. 4

Case 3-Aneurysmal bone cyst of the lumbar spine. Figure 3-The laminae, inferior articular processes and spinous process of the fourth lumbar vertebra are expanded. The limiting layer of new bone is very thin and difficult to see. Figure 4-The microscopic features have been modified by the effect of radiotherapy $(1,300 \mathrm{r})$ given six weeks before biopsy. Vascular spaces can still be seen and there is much loose fibrous tissue. (Haematoxylin and eosin, $\times 100$.)

of the lesion is limited by a clearly demarcated, smooth and in places rather sclerotic layer of bone. In the spine the dorsal processes are more commonly involved than the bodies (Figs. 3 and 5). In the long bones the lesion is usually eccentric and placed towards the end of the bone, involving the diaphysis and the metaphysis (Figs. 6 to 8) but not the epiphysial part unless the epiphysis has fused, as in Case 11 (Fig. 9).

Variations from this picture occur. Expansion was present in all but was not marked in some (Figs. 6, 7 and 12). The cyst was not eccentric in five of the ten tubular bone cases (Figs. 12, 14, 15, 16 and 17). As was noted by Sherman and Soong (1957) when the lesion is in the upper humerus (Fig. 16), a small tubular bone (Fig. 14) or a slender long bone (Fig. 15), it is usually symmetrically placed within the bone and uniformly expanded. Radiological 
TABLE I

The Features of Twelve Aneurysmal Bone Cysts

\begin{tabular}{|c|c|c|c|c|c|c|c|}
\hline \multirow{2}{*}{$\begin{array}{c}\text { Case } \\
\text { number }\end{array}$} & \multirow{2}{*}{$\begin{array}{c}\text { Age } \\
\text { (years) }\end{array}$} & \multirow[b]{2}{*}{ Sex } & \multirow[b]{2}{*}{ Site } & \multirow{2}{*}{ Symptoms } & \multirow{2}{*}{ Preceding trauma } & \multicolumn{2}{|c|}{ Radiological features } \\
\hline & & & & & & $\begin{array}{l}\text { Central or } \\
\text { eccentric }\end{array}$ & Expansion \\
\hline 1 & 22 & Female & $\begin{array}{c}\text { Whole of middle } \\
\text { phalanx of } \\
\text { index finger }\end{array}$ & $\begin{array}{l}\text { Two weeks pain } \\
\text { and swelling }\end{array}$ & $\begin{array}{c}\text { Onset of symptoms } \\
\text { followed } \\
\text { minor trauma }\end{array}$ & $\begin{array}{l}\text { Whole } \\
\text { phalanx }\end{array}$ & Marked \\
\hline 2 & 15 & Male & $\begin{array}{l}\text { Upper } \\
\text { metaphysis } \\
\text { of fibula }\end{array}$ & $\begin{array}{l}\text { Swelling for } \\
\text { three months. } \\
\text { No pain }\end{array}$ & None & Central & Marked \\
\hline 3 & 7 & Male & $\begin{array}{l}\text { Spinous process } \\
\text { and laminae } \\
\text { of fourth } \\
\text { lumbar vertebra }\end{array}$ & $\begin{array}{l}\text { Pain and swelling } \\
\text { for three days }\end{array}$ & $\begin{array}{l}\text { Onset of symptoms } \\
\text { followed a fall }\end{array}$ & - & Marked \\
\hline 4 & 9 & Female & $\begin{array}{c}\text { Upper } \\
\text { metaphysis } \\
\text { of tibia }\end{array}$ & $\begin{array}{l}\text { Gradually enlarging } \\
\text { swelling for } \\
\text { four months }\end{array}$ & $\begin{array}{c}\text { A blow at } \\
\text { onset of symptoms }\end{array}$ & Eccentric & Moderate \\
\hline 5 & 15 & Male & $\begin{array}{l}\text { Upper } \\
\text { metaphysis } \\
\text { of humerus }\end{array}$ & $\begin{array}{l}\text { Presented with a } \\
\text { pathological } \\
\text { fracture }\end{array}$ & None & Central & Marked \\
\hline 6 & 8 & Male & $\begin{array}{l}\text { Lower } \\
\text { metaphysis } \\
\text { of tibia }\end{array}$ & $\begin{array}{l}\text { Swelling first noticed } \\
\text { the day before. } \\
\text { No pain }\end{array}$ & None & Eccentric & Moderate \\
\hline 7 & 7 & Female & $\begin{array}{l}\text { Lower } \\
\text { metaphysis } \\
\text { of tibia }\end{array}$ & $\begin{array}{c}\text { Pain for } \\
\text { several weeks }\end{array}$ & None & Central & Marked \\
\hline 8 & 6 & Male & $\begin{array}{l}\text { Lower } \\
\text { metaphysis } \\
\text { of femur }\end{array}$ & $\begin{array}{l}\text { Pain and swelling } \\
\text { for two weeks }\end{array}$ & $\begin{array}{l}\text { A blow at onset } \\
\text { of symptoms }\end{array}$ & Eccentric & Moderate \\
\hline 9 & 15 & Female & $\begin{array}{l}\text { Spinous process } \\
\text { of the third } \\
\text { cervical vertebra }\end{array}$ & $\begin{array}{l}\text { Swelling noticed a } \\
\text { few days earlier on } \\
\text { changing hair style }\end{array}$ & None & - & Marked \\
\hline 10 & 10 & Male & $\begin{array}{l}\text { Trochanteric } \\
\text { region } \\
\text { of femur }\end{array}$ & $\begin{array}{l}\text { Pathological } \\
\text { fracture }\end{array}$ & None & Central & $\begin{array}{c}\text { None at first } \\
\text { but later } \\
\text { becoming } \\
\text { marked }\end{array}$ \\
\hline 11 & 17 & Male & $\begin{array}{l}\text { Head and neck } \\
\text { of femur }\end{array}$ & $\begin{array}{l}\text { Pain and limp } \\
\text { for six months }\end{array}$ & $\begin{array}{c}\text { Several years earlier } \\
\text { fell from height } \\
\text { breaking } \\
\text { opposite tibia }\end{array}$ & Eccentric & Marked \\
\hline 12 & 56 & Female & $\begin{array}{l}\text { Upper } \\
\text { diaphysis } \\
\text { of fibula }\end{array}$ & $\begin{array}{l}\text { Pathological } \\
\text { fracture }\end{array}$ & None & Eccentric & Moderate \\
\hline
\end{tabular}


TABLE I-continued

The Features of Twelve Aneurysmal Bone Cysts

\begin{tabular}{|c|c|c|c|c|}
\hline $\begin{array}{l}\text { Operative } \\
\text { findings }\end{array}$ & $\begin{array}{l}\text { Histological } \\
\text { features }\end{array}$ & Treatment & Progress & $\begin{array}{l}\text { Particular points } \\
\text { of interest }\end{array}$ \\
\hline Blood-filled cyst & Typical & $\begin{array}{l}\text { Curettage and } \\
\text { cancellous graft }\end{array}$ & $\begin{array}{l}\text { Recurrence within } \\
\text { eight months. } \\
\text { Total excision. } \\
\text { Seven years- } \\
\text { no recurrence }\end{array}$ & $\begin{array}{c}\text { Age. } \\
\text { Unusual site. } \\
\text { Recurrence after } \\
\text { curettage }\end{array}$ \\
\hline Blood-filled cyst & Typical & Total excision & $\begin{array}{l}\text { Three years- } \\
\text { no recurrence }\end{array}$ & $\begin{array}{l}\text { Painless. } \\
\text { Central site in the bone } \\
\text { with uniform expansion }\end{array}$ \\
\hline $\begin{array}{l}\text { Avascular fibro- } \\
\text { gelatinous material } \\
\text { (six weeks after } \\
\text { radiotherapy) }\end{array}$ & $\begin{array}{l}\text { Atypical. } \\
\text { Fibrous tissue with } \\
\text { much new bone. } \\
\text { Some areas more } \\
\text { typical }\end{array}$ & $\begin{array}{l}\text { Radiotherapy. } \\
\text { Six weeks later- } \\
\text { curettage }\end{array}$ & $\begin{array}{l}\text { Six years- } \\
\text { no recurrence } \\
\text { then lost to } \\
\text { follow-up }\end{array}$ & $\begin{array}{l}\text { Atypical operative and } \\
\text { histological features. } \\
\text { Age, site and radio- } \\
\text { logical features all } \\
\text { support the diagnosis }\end{array}$ \\
\hline $\begin{array}{c}\text { First operation- } \\
\text { serosanguinous fluid. } \\
\text { Second operation- } \\
\text { blood-filled cyst }\end{array}$ & Typical & $\begin{array}{l}\text { Curettage and } \\
\text { cancellous graft }\end{array}$ & $\begin{array}{l}\text { Five months- } \\
\text { recurrence. } \\
\text { Repeat curettage. } \\
\text { Five years- } \\
\text { no recurrence }\end{array}$ & $\begin{array}{l}\text { Unusual operative } \\
\text { findings on the } \\
\text { first occasion. } \\
\text { Recurrence after } \\
\text { curettage }\end{array}$ \\
\hline $\begin{array}{l}\text { Fleshy vascular } \\
\text { material. Bleeding } \\
\text { a marked feature }\end{array}$ & Typical & $\begin{array}{l}\text { Curettage and } \\
\text { cancellous graft }\end{array}$ & $\begin{array}{l}\text { Five years- } \\
\text { no recurrence }\end{array}$ & $\begin{array}{l}\text { Central site in the bone } \\
\text { with uniform expansion }\end{array}$ \\
\hline $\begin{array}{l}\text { Soft grey tissue. } \\
\text { Little bleeding }\end{array}$ & $\begin{array}{l}\text { Some areas typical. } \\
\text { Others suggestive } \\
\text { of fibrous dysplasia }\end{array}$ & $\begin{array}{l}\text { Curettage and } \\
\text { sliding cortical } \\
\text { graft }\end{array}$ & $\begin{array}{l}\text { Four years- } \\
\text { no recurrence }\end{array}$ & $\begin{array}{l}\text { Atypical contents. } \\
\text { Areas of atypical } \\
\text { histology }\end{array}$ \\
\hline $\begin{array}{l}\text { Blood-filled cyst. } \\
\text { Fleshy vascular } \\
\text { material filled } \\
\text { one-third of the cyst }\end{array}$ & $\begin{array}{l}\text { Typical but in the } \\
\text { solid areas } \\
\text { resembled } \\
\text { giant-cell tumour }\end{array}$ & $\begin{array}{l}\text { Curettage and } \\
\text { cancellous graft }\end{array}$ & $\begin{array}{l}\text { Recurrence within } \\
\text { eight months. } \\
\text { Radiotherapy. } \\
\text { Ten years- } \\
\text { no recurrence }\end{array}$ & $\begin{array}{l}\text { Recurrence after } \\
\text { curettage }\end{array}$ \\
\hline $\begin{array}{l}\text { Firm and rather } \\
\text { avascular tissue }\end{array}$ & $\begin{array}{l}\text { Some areas typical, } \\
\text { others resembled } \\
\text { chondromyxoid } \\
\text { fibroma }\end{array}$ & $\begin{array}{l}\text { Curettage and } \\
\text { cancellous graft }\end{array}$ & $\begin{array}{l}\text { Recurrence after } \\
\text { four years. } \\
\text { Repeat curettage. } \\
\text { Performed recently }\end{array}$ & $\begin{array}{c}\text { Atypical operative } \\
\text { findings. Areas of } \\
\text { atypical histology. } \\
\text { Recurrence after curettage }\end{array}$ \\
\hline Blood-filled cyst & Typical & $\begin{array}{l}\text { Partial excision } \\
\text { and curettage }\end{array}$ & $\begin{array}{c}\text { Thirteen years- } \\
\text { no recurrence }\end{array}$ & Painless \\
\hline Blood-filled cyst & Typical & $\begin{array}{c}\text { Initially no } \\
\text { treatment. Rapid } \\
\text { expansion. } \\
\text { Partial curettage. } \\
\text { Radiotherapy }\end{array}$ & $\begin{array}{l}\text { One year- } \\
\text { no recurrence }\end{array}$ & $\begin{array}{l}\text { Initial central site } \\
\text { and no expansion. } \\
\text { Rapid growth }\end{array}$ \\
\hline $\begin{array}{l}\text { Dark red friable and } \\
\text { vascular material }\end{array}$ & Typical & $\begin{array}{l}\text { Total excision. } \\
\text { Austin Moore } \\
\text { prosthesis }\end{array}$ & $\begin{array}{l}\text { Nine months- } \\
\text { no recurrence }\end{array}$ & $\begin{array}{l}\text { Epiphysial part of bone } \\
\text { involved but the } \\
\text { epiphysial line had closed }\end{array}$ \\
\hline $\begin{array}{l}\text { Blood-filled cyst. } \\
\text { Some spongy } \\
\text { vascular tissue }\end{array}$ & Typical & Total excision & $\begin{array}{l}\text { Three years- } \\
\text { no recurrence }\end{array}$ & $\begin{array}{l}\text { The age was against the } \\
\text { diagnosis but all other } \\
\text { features supported it }\end{array}$ \\
\hline
\end{tabular}

VOL. $50 \mathrm{~B}$, NO. 1, FEBRUARY 1968 


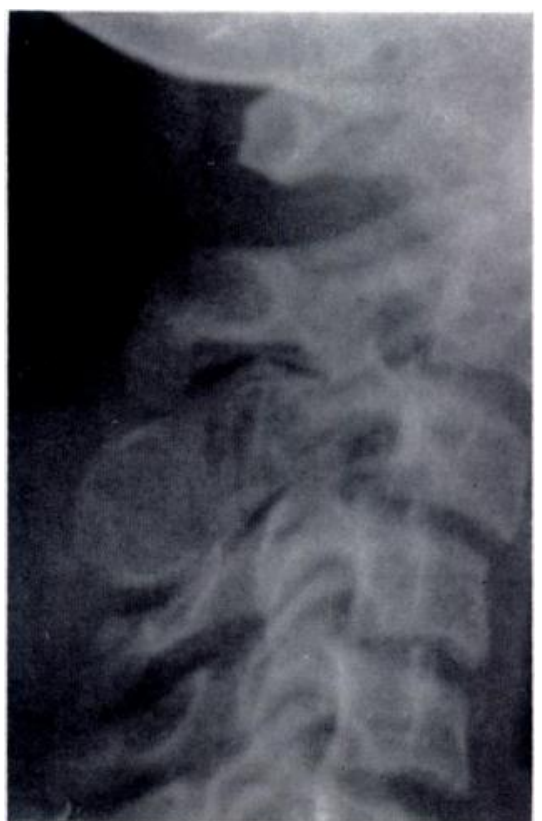

Fig. 5

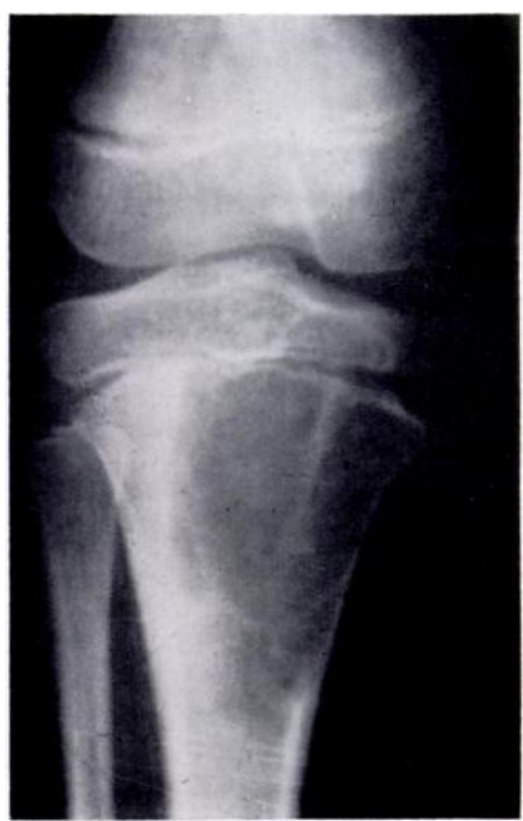

FiG. 6

Figure 5-Case 9. Aneurysmal bone cyst of the cervical spine. The spinous process of the third cervical vertebra is markedly expanded. Figure 6-Case 4. Aneurysmal bone cyst of the upper tibial metaphysis. The cyst is eccentrically placed but expansion is not a notable feature.

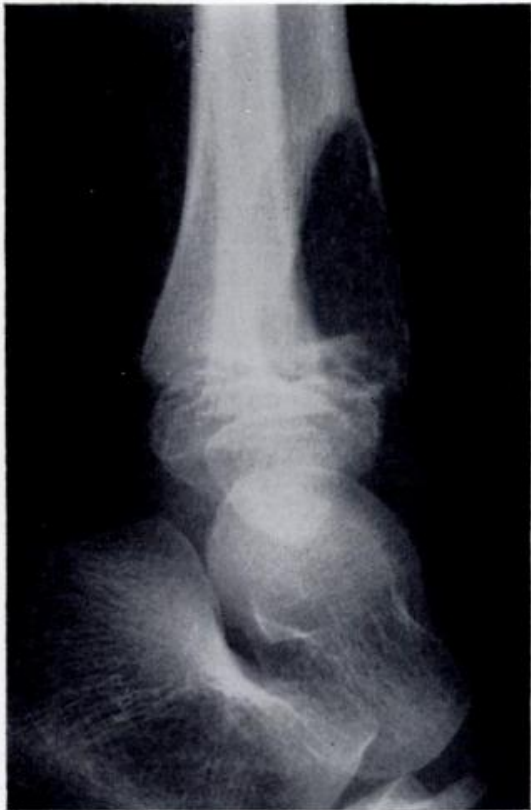

FIG. 7

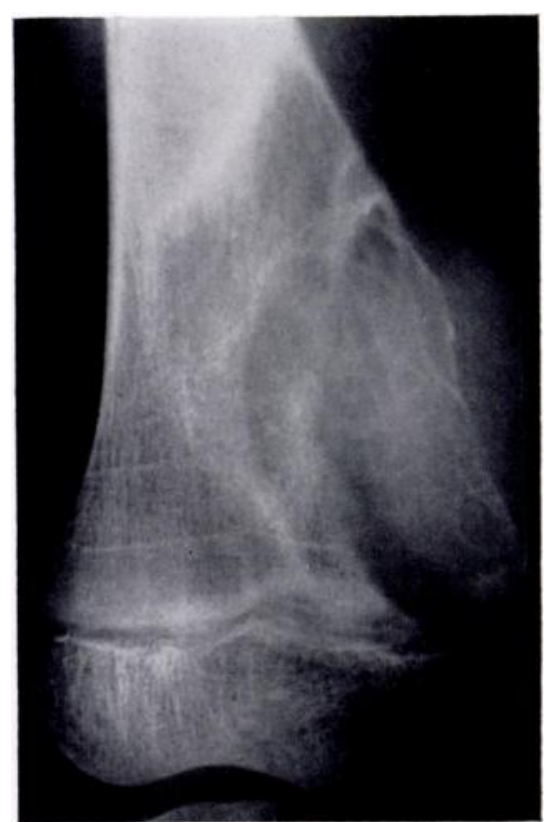

Fig. 8

Figure 7-Case 6. An eccentrically placed aneurysmal bone cyst in the lower metaphysis of the tibia. The overlying cortex has disappeared and the cyst is bounded by a thin layer of subperiosteal bone. Expansion is present but not marked. Figure 8-Case 8. An eccentrically placed aneurysmal bone cyst in the metaphysis and diaphysis of the lower end of the femur. 
diagnosis is usually possible with the more typical features occurring in the immature skeleton but in some instances other conditions have to be considered.

The giant-cell tumour differs in several respects. It is rare before the age of twenty but sometimes occurs in the immature skeleton. It arises in that part of the bone which was formerly the epiphysis and in the spine it is rare except in the sacrum. A unicameral bone cyst differs in being uniformly and less markedly expanded. The cortex is always intact except when there has been a pathological fracture. The upper metaphysis of the humerus is a common site for the unicameral cyst. When the aneurysmal bone cyst arises in this situation it is also

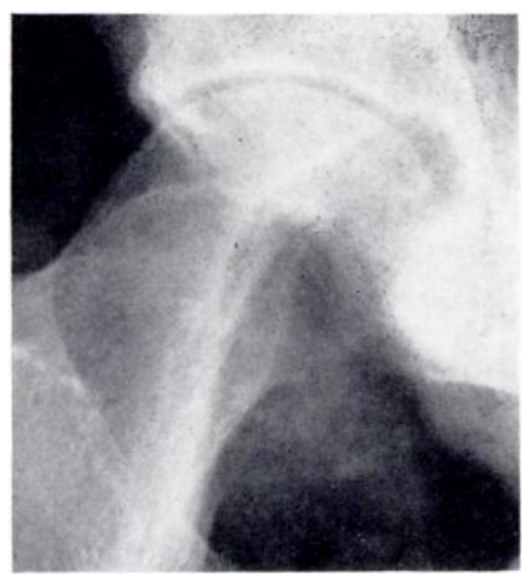

Fig. 9

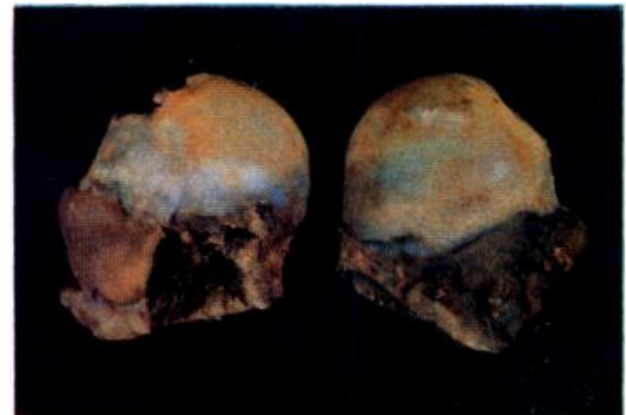

Fig. 10

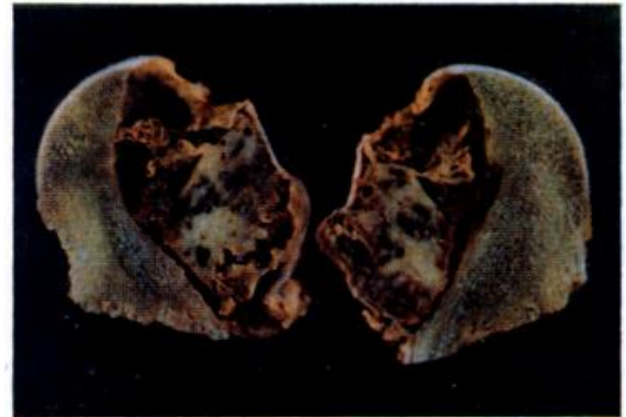

Fig. 11

Case 11-Aneurysmal bone cyst of the head and neck of the femur. Figure 9-The cyst is eccentrically placed and there is marked expansion but the site is unusual in that the very extremity of the bone is involved. However, it is possible that spread to the epiphysial part took place after closure of the epiphysial plate. Figures 10 and 11 show the macroscopic appearances. The head and neck of the femur have been divided in half and the external and internal surfaces are shown. Typical blood-filled spaces and a rather large amount of solid tissue are seen.

usually symmetrically placed within the bone and expands uniformly. A good deal of similarity may be present in both lesions.

Haemangioma of a vertebra occurs in the body and can be distinguished by the vertical striations, lack of expansion, and often the presence of like changes in other vertebral bodies. Occasionally in aneurysmal bone cyst the absence of a limiting bony layer may raise the possibility of a malignant tumour, but the presence of an intraosseous smooth line of demarcation will indicate the true nature of the lesion.

None of the lesions reported here was investigated by angiography. In view of their vascular nature it might be expected that such cysts would give a distinctive picture. Schobinger and Stoll (1957) noted a diffuse opacity of the cystic area during the venous phase in the one

VOL. $50 \mathrm{~B}$, No. 1, february 1968 
case they studied. Lindbom, Soderberg, Spjut and Sunnqvist (1961) reported the findings in three further cases. The arteries leading to the lesion were dilated; there was a slight but definite patchy opacity throughout the area of the cyst; and the veins leaving the lesion were filled earlier than other veins, indicating an arteriovenous shunt through the lesion. Further studies are necessary to determine if this form of investigation has any value.

\section{OPERATIVE FINDINGS}

The characteristic appearance is of a very thin outer shell of bone which, when breached, releases a free flow of blood which appears to be venous in origin by the manner in which it wells up and by its dark colour. In addition the cyst contains a variable amount of solid tissue. This is in the form of a friable vascular tissue lining the walls and subdividing the cyst into a series of blood-filled loculi. Often a part of the cyst is filled with a more solid mass of soft tissue (Figs. 10 and 11). The vascular element may be much less in evidence and the solid tissue be present in larger amounts, or the cyst may be filled with a sero-sanguinous fluid. The areas of solid tissue could be the remaining tissue of a pre-existing lesion; the result of a process of natural repair; or they may be due to previous radiotherapy, as probably in Case 3 (Fig. 4).

\section{HISTOLOGY}

The histological structure of this rather uncommon lesion has been well described in the original papers of Jaffe and Lichtenstein (1942) who were largely responsible for its recognition as an entity. The most striking and essential feature in a well preserved specimen is the numerous dilated blood spaces irregularly margined by small osteoclastic giant cells. These spaces have more or less delicate walls of loose-texture fibrous tissue containing scattered islets of osteoid and/or bone (Fig. 2). Elsewhere there may be a surprising amount of richly vascularised undifferentiated connective tissue with numerous giant cells (Fig. 19), or areas showing poorly formed cartilage and osteoid. This more solid material may thus arouse the suspicion of osteoblastoma, chondroblastoma, chondromyxoid fibroma and non-osteogenic fibroma, and certain rarer lesions which may defy certain diagnosis, save that of " benign unspecified tumour." It should also be remembered that tissue simulating aneurysmal bone cyst may occasionally form part of the wall of an otherwise typical simple unicameral bone cyst.

The cytological detail of aneurysmal bone cyst merits a careful study, as it must be distinguished from telangiectatic forms of osteosarcoma. There may be a lot of solid cellular tissue in aneurysmal bone cyst, showing a variety of cell types, often including numerous osteoclasts; but none of the cells, whether fibroblast, osteoblasts or other types, will diverge greatly from the appearances seen in reactive tissues. The ominous irregularity in cell size and morphology of osteosarcoma are absent, the cell nuclei being normochromatic. Mitoses may be quite numerous in aneurysmal bone cyst, but are of normal pattern and seen among groups of cells, rather than dispersed through the whole tissue; moreover, tumour giant cells are absent. Aneurysmal bone cyst may show a good deal of osteoid, not only in the narrow septae between the blood spaces, but also in the solid areas. This again is more mature and lacks the atypical appearance of the osteosarcoma matrix.

Despite these histological dissimilarities the differential diagnosis between aneurysmal bone cyst and osteosarcoma may, histologically, be extremely perplexing and the dilemma is most likely to arise in a vertebra. The patient may be a child or adolescent, and, although the appropriate treatment in either instance is almost certain to be radiotherapy, the importance of the diagnosis is emphasised since it will decide the dose level of irradiation to be applied to the lesion. The solution of this problem calls for the closest liaison between the surgeon, radiologist, radiotherapist and pathologist, with a shrewd appraisal of the surgical findings at the time of the biopsy, the radiographic appearances (including tomographs) and the macroscopic and microscopic details of the tissue taken at biopsy. 


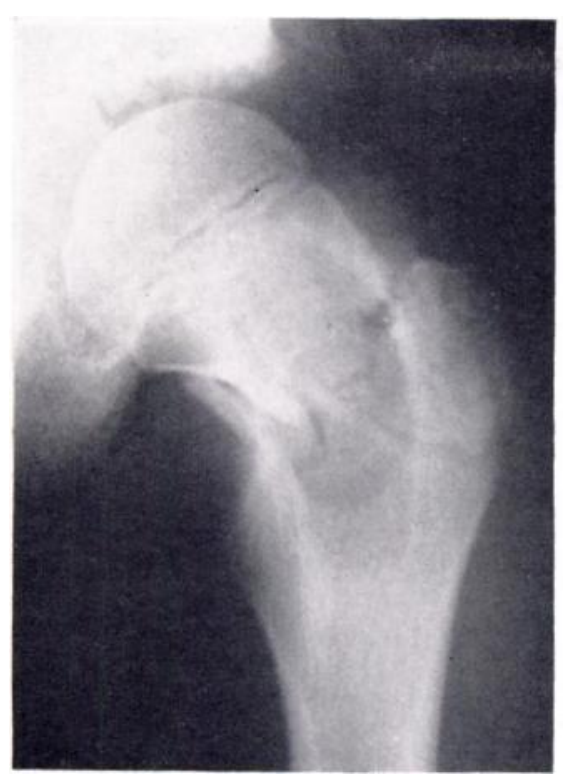

FIG. 12

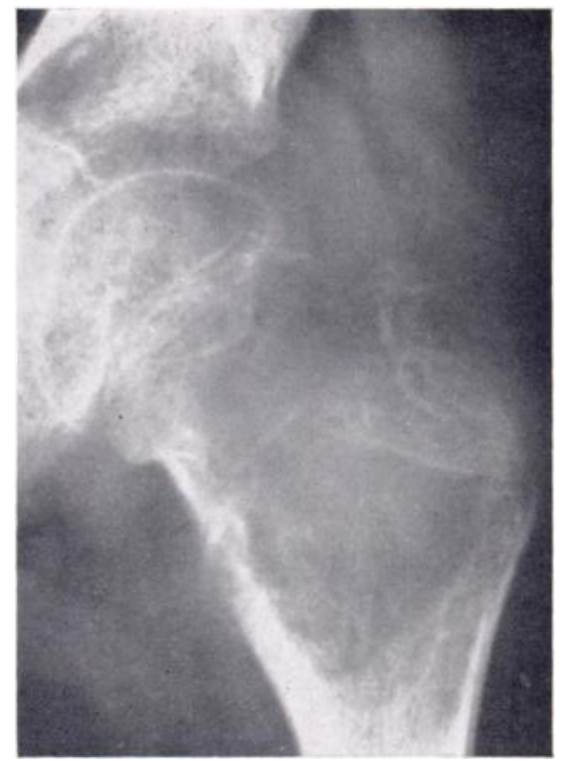

FIG. 13

Case 10-Figure 12 shows a pathological fracture through an aneurysmal bone cyst in the trochanteric region of the femur. Figure 13 shows the development of marked expansion four months later.

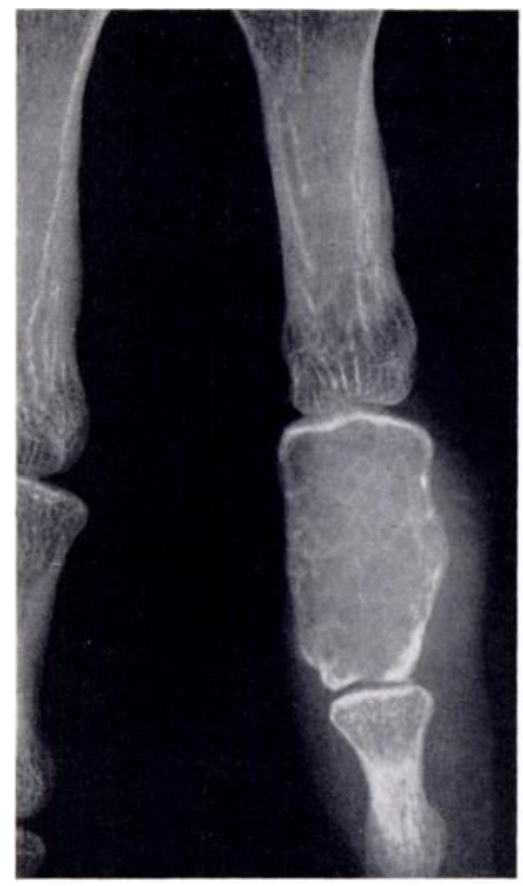

FIG. 14

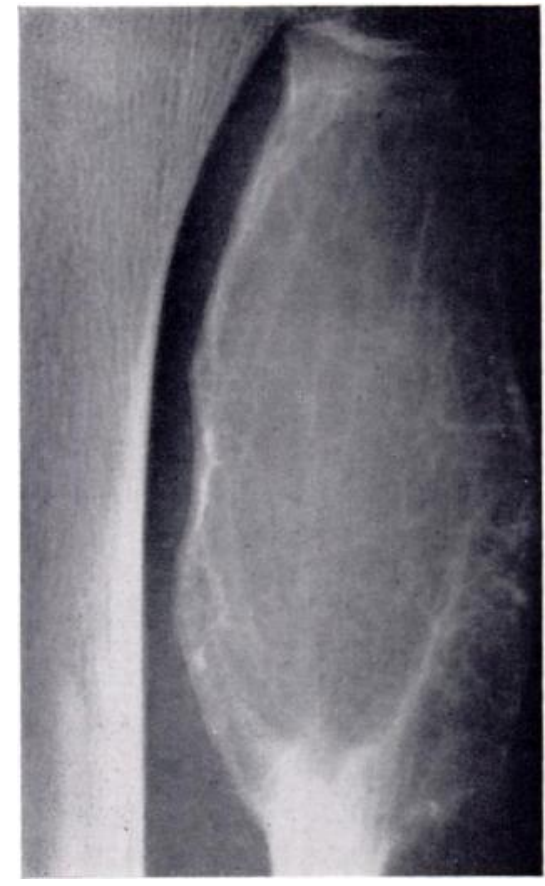

Fig. 15

Figure 14-Case 1. An aneurysmal bone cyst occupying the whole of the middle phalanx of the index finger. Expansion of the bone is shown. Figure 15-Case 2. A centrally placed cyst, with marked expansion, involving the metaphysis and diaphysis of the upper end of the fibula. 
Haemangioma of bone displays some of the vascular features found in aneurysmal bone cyst, but is usually devoid of the giant-celled and fibroblastic reactive element unless there has been considerable extravasation of blood which will provoke this non-specific type of reaction. Moreover, the individual blood vessels of a haemangioma are of a more conventional pattern, usually showing an endothelial lining which is missing from the somewhat irregular blood-containing channels of aneurysmal bone cyst. The histological separation from giantcell tumour is usually quite easy, as this lesion, although often well supplied with blood vessels, fails to show this feature as a dominant structural component, and furthermore it does not as a rule show osteogenic elements. Sometimes, however, this distinction cannot be made microscopically, and it should be remembered that giant-cell tumours, although rare in young patients, do sometimes appear at an early age and in unusual sites.

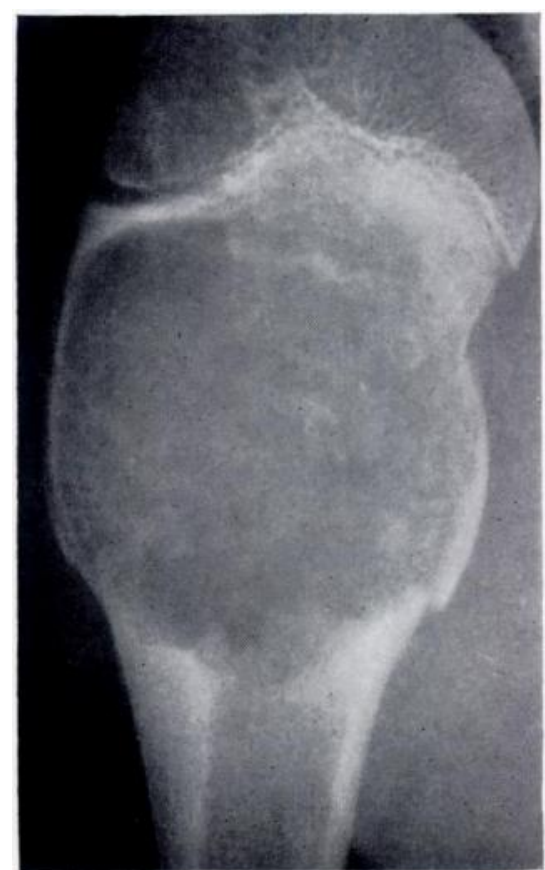

FIG. 16

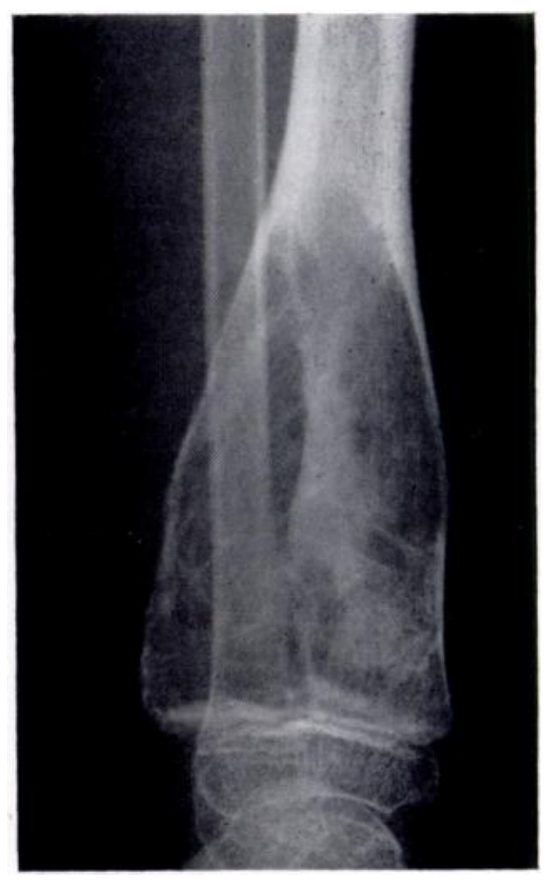

FIG. 17

Figure 16-Case 5. A pathological fracture through a well expanded and symmetrically placed cyst in the upper metaphysis of the humerus. Figure 17-Case 7. Aneurysmal bone cyst of the lower metaphysis and diaphysis of the tibia. The cyst is symmetrically placed and quite markedly expanded.

Confusion may arise at times with fibrous dysplasia of bone which may be simulated by the more or less osteogenic solid areas of aneurysmal bone cyst. Here again, in the absence of the characteristic blood-filled and communicating spaces of aneurysmal bone cyst, diagnosis may be uncertain, but the presence of this feature will indicate the true nature of the lesion.

If a lesion is injured before biopsy the histological diagnosis may be obscured by the presence of reactive tissue; it is then important to assess the evidence of the vascular as against cystic lesional tissue among the products of reaction to trauma.

Diagnosis of aneurysmal bone cyst may be well summarised by stating that, after excluding the possibility of malignancy, micro-anatomy is the key to its recognition.

\section{TREATMENT}

Aneurysmal bone cyst is a benign condition and instances of spontaneous regression (Sherman and Soong 1957) and of regression after minor surgical interference have been 
noted (Besse, Dahlin, Bruwer, Svien and Ghormley 1953). It might therefore be thought that surgical treatment need not necessarily aim at the complete eradication of the lesion. Lichtenstein (1957), however, warned against this when reporting four recurrences after

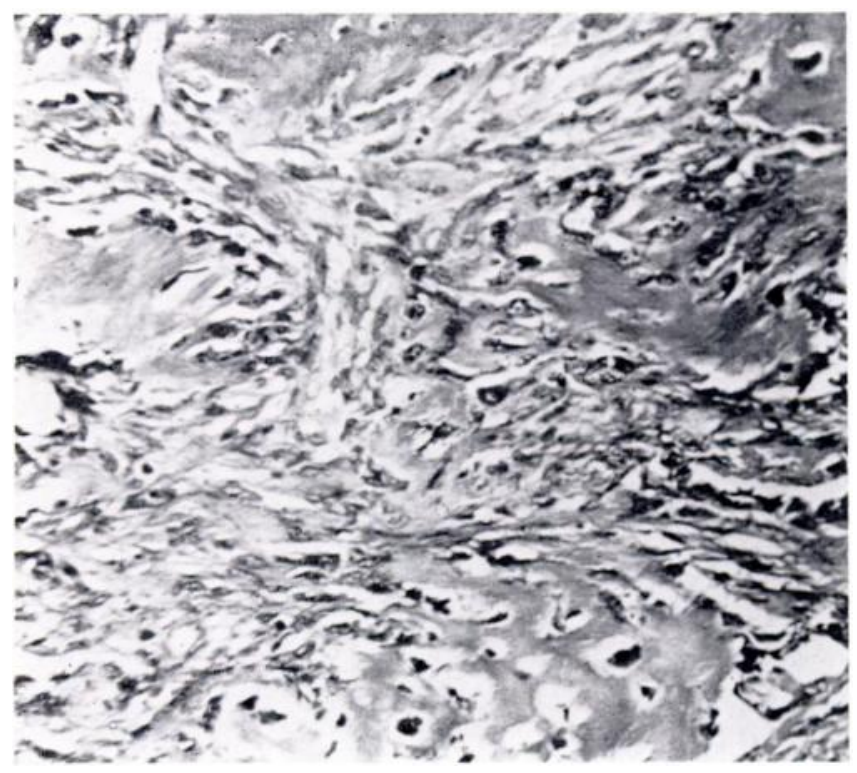

FIG. 18

Case 6-An area with the appearance of fibrous dysplasia. (Haematoxylin and eosin, 100.)

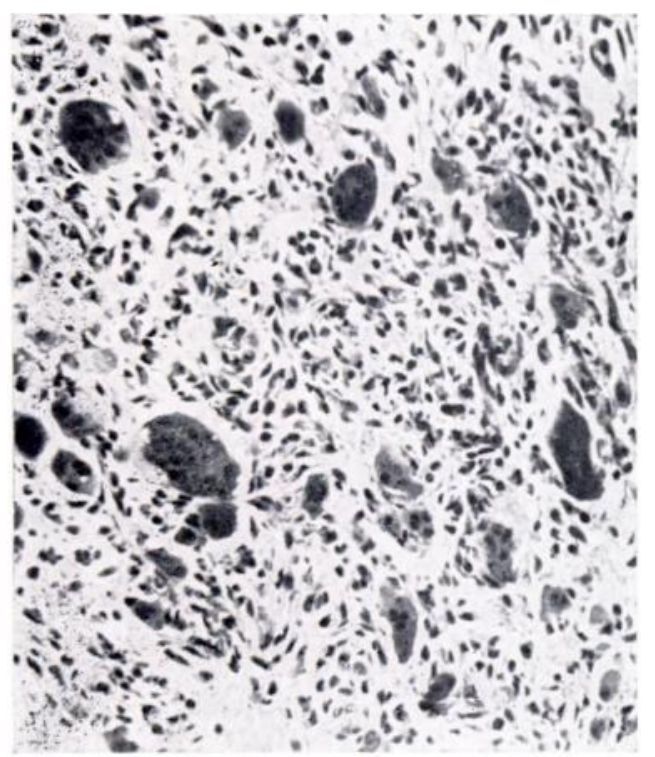

Fig. 19

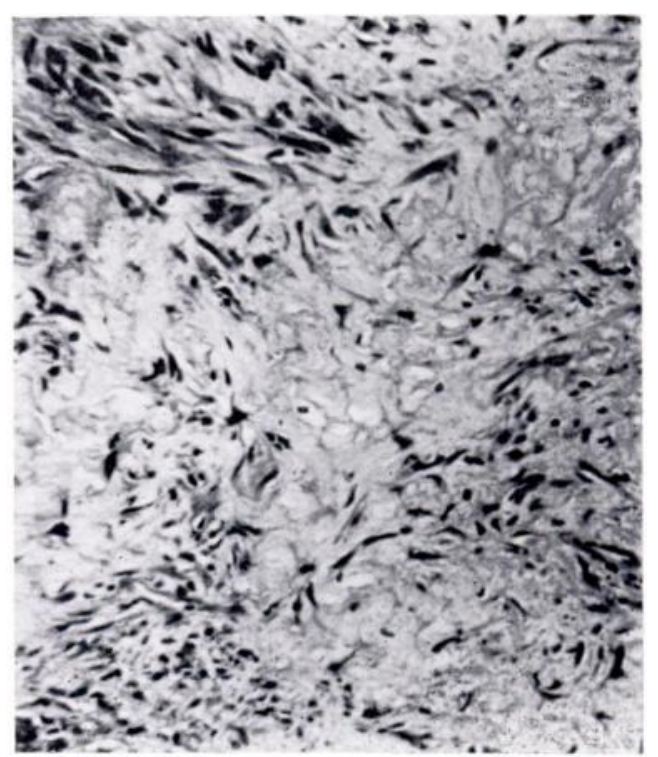

Fig. 20

Figure 19-Case 7. A section with the appearances of a giant-cell tumour. (Haematoxylin and eosin, 200.) Figure 20-Case 8. A section showing the appearances of chondromyxoid fibroma. (Haematoxylin and cosin, $\because 200$.)

incomplete curettage. Careful curettage and bone grafting were the initial treatment in six of our cases. It is significant that four of these cysts continued to grow and required further treatment in the form of local excision (Case 1), repeat curettage (Cases 4 and 8) and 
radiotherapy (Case 7). It seems therefore that complete local excision is the treatment of choice when this would not interfere with function. Failing this, thorough curettage and bone grafting should be carried out and if necessary repeated. Radiotherapy should be reserved for the situation where surgical access is difficult or impossible. The possibility of damage to the epiphysial plate with subsequent interference with growth should preclude its use in the majority of cases. In vertebral cases damage to the spinal cord and sterilisation are risks which must be considered.

\section{PATHOGENESIS}

The nature and origin of aneurysmal bone cyst remains unknown, though all accounts indicate it to be a benign condition and not a neoplasm. The most favoured view of its origin is that of a vascular disturbance (Jaffe 1950, Lichtenstein 1950, Donaldson 1962) in the form of a sudden venous occlusion or the development of an arteriovenous shunt. It is not known if this takes place in normal bone or if it happens in a pre-existing lesion, as is now favoured by Jaffe (1962), and which is supported by the finding of tissue suggestive of chondromyxoid fibroma in Case 8 (Fig. 20), and of fibrous dysplasia in Case 6 (Fig. 18).

Trauma has been put forward as an important etiological factor (Thompson 1954, Barnes 1956). In the cases reported here there was only one instance (Case 4) of an injury which could possibly have initiated the bone changes. In the other cases trauma had only drawn attention to an existing lesion. Even if trauma can be accepted as a cause of aneurysmal bone cysts there must be other factors. How else is it possible to reconcile the rarity of aneurysmal bone cysts with the vast number of bone injuries?

Edling (1965) regarded aneurysmal bone cyst as one of the manifestations of solitary dysfibroplasia of bone. This term, introduced by McWhirter (1952), is used to include a variety of bone lesions including aneurysmal bone cyst, unicameral bone cyst, fibrous dysplasia and giant-cell tumour, which they consider to be due to errors in development of the epiphysial plate. Whilst it is accepted that aneurysmal and unicameral bone cysts have many features in common, the same cannot be said for giant-cell tumour, occurring as it does in the mature skeleton and behaving in a neoplastic and indeed sometimes in a malignant manner. Furthermore, if as seems true aneurysmal bone cyst can sometimes develop in the mature skeleton, how can its origin be attributed to a growth defect of the epiphysial plate?

On pondering these three possibilities concerning the pathogenesis of aneurysmal bone cyst, one should take note of two features - the characteristic site of the lesion near the growth cartilage of the juvenile bone (the most vascular region) and the brevity of symptoms in many cases. The rapid growth of the lesion can sometimes be demonstrated as in Case 10 (Figs. 12 and 13). One of us recently examined a fulminating cystic tumour of a dog's tibia which attained large size in five weeks and consisted mainly of blood-distended cysts rather similar to those seen in aneurysmal bone cyst, although the small amount of solid tumour present showed the structure of conventional osteosarcoma. A description of this canine tumour has been published (Price and Sumner-Smith 1966) under the name " malignant bone aneurysm" as its rapid progress was thought to have been due to aneurysmal distension of the blood spaces. This telangectatic type of osteosarcoma sometimes appears in young persons and likewise displays rapid growth, marked bone destruction, pathological fracture and a bad prognosis. Possibly this type of sarcoma is the malignant counterpart of aneurysmal bone cyst and comparable with the occasional benign tumours which may be involved by the hypothetical vascular disturbance considered by some to be the cause of this cystic lesion.

Aneurysmal bone cyst clearly differs from haemangioma of bone, but one may advance the view that it may be either a primary lesion or a secondary evolution in a number of conditions, including both benign and perhaps malignant neoplasms. We have seen three examples of juvenile bone cysts, oddly enough all in the lower end of the fibula, in which small areas of the walls showed the microscopic blood-filled giant-cell margined spaces seen 
in aneurysmal bone cyst. It has been found impossible to decide whether these lesions are unicameral bone cysts or aneurysmal bone cysts. Having some of the features of both, they appear to take up a position somewhere between the two. Thus the concept of the evolutionary change may offer a link between the vascular hypothesis and the concept of a close relationship between aneurysmal bone cyst, unicameral bone cyst and fibrous dysplasia-a point of view to which, with certain reservations, we subscribe.

In the absence of any new information therefore, it still seems reasonable to attribute the origin of the aneurysmal bone cyst to a dynamic vascular change occurring usually in the more vascular, newly formed parts of the immature skeleton and possibly arising, in some cases at least, in a pre-existing lesion. What initiates this vascular change is conjectural, but in some instances trauma might play a part.

\section{SUMMARY}

1. The clinical, radiological, operative and histological features of twelve aneurysmal bone cysts are recorded.

2. Attention is drawn to atypical features, and the problem of diagnosis is discussed.

3. It is recommended that treatment should be complete excision, except where this would interfere with function.

4. Various theories on pathogenesis are considered and favour given to the view that these cysts result from a local change in haemodynamics occurring possibly in a pre-existing lesion.

It is a pleasure to acknowledge the help given during the preparation of this paper by Mr A. L. Eyre-Brook. Also, we would like to thank the following surgeons for permission to publish their cases: Mr H. K. Bourns, Mr B. H. Brock, Mr N. Capener, Mr L. Henry, Mr V. S. Hughes-Davies, Mr H. K. Lucas, Mr M. P. McCormack, Mr B. K. Madden and Mr R. Merryweather.

We are also grateful to Mr J. E. Hancock for producing the illustrations. All the patients referred to in this paper are included in the Bristol Bone Tumour Registry which has the support of the British Empire Cancer Campaign.

\section{REFERENCES}

BARNes, R. (1956): Aneurysmal Bone Cyst. Journal of Bone and Joint Surgery, 38-B, 301.

Besse, B. E., Dahlin, D. C., Bruwer, A., Svien, H. J., and Ghormley, R. K. (1953): Aneurysmal Bone Cyst. Proceedings of the Staff Meetings of the Mayo Clinic, 28, 249.

Crabbe, W. A. (1962): Aneurysmal Bone Cyst and its Atypical Features. Guy's Hospital Reports, 111, 347.

Cruz, M., and Coley, B. L. (1956): Aneurysmal Bone Cyst. Surgery, Gynecology and Obstetrics, 103, 67.

Dahlin, D. C., Besse, B. E., Pugh, D. G., and Ghormley, R. K. (1955): Aneurysmal Bone Cysts. Radiology, 64, 56.

Donaldson, W. F., Jun. (1962): Aneurysmal Bone Cyst. Journal of Bone and Joint Surgery, 44-A, 25.

Edling, N. P. G. (1965): Is the Aneurysmal Bone Cyst a True Pathologic Entity? Cancer, 18, 1127.

JAFFe, H. L. (1950): Aneurysmal Bone Cyst. Bulletin of the Hospital for Joint Diseases, 11, 3.

JAFFE, H. L. (1958): Tumors and Tumorous Conditions of the Bones and Joints. Philadelphia: Lea and Febiger.

JAfFe, H. L. (1962): Discussion Following a Paper by Donaldson, W. F., Jun., Aneurysmal Bone Cyst. Journal of Bone and Joint Surgery, 44-A, 40.

JAfFe, H. L., and Lichtenstein, L. (1942): Solitary Unicameral Bone Cyst with Emphasis on the Roentgen Picture, the Pathologic Appearance, and the Pathogenesis. Archives of Surgery, 44, 1004.

Lichtenstein, L. (1950): Aneurysmal Bone Cyst: A Pathological Entity Commonly Mistaken for Giant-Cell Tumor and Occasionally for Hemangioma and Osteogenic Sarcoma. Cancer, 3, 279.

Lichtenstein, L. (1953): Aneurysmal Bone Cyst: Further Observations. Cancer, 6, 1228.

Lichtenstein, L. (1957): Aneurysmal Bone Cyst. Journal of Bone and Joint Surgery, 39-A, 873.

Lindbom, A., Soderberg, G., SPJut, H. J., and Sunnevist, O. (1961): Angiography of Aneurysmal Bone Cyst. Acta Radiologica, 55, 12.

McWhirter, R. (1952): Giant-Cell Tumours, Osteitis Fibrosa, and Bone Cysts. Journal of the Faculty of Radiologists, 4, 1.

Price, C. H. G., and Sumner-Smith, G. (1966): “ Malignant Bone Aneurysm ” in a Dog: an Unusual Example of Osteosarcoma. British Veterinary Journal, 122, 51.

Schobinger, R., and Stols, H. C. (1957): The Arteriographic Picture of Benign Bone Lesions Containing Giant Cells. Journal of Bone and Joint Surgery, 39-A, 953.

Sherman, R. S., and Soong, K. Y. (1957): Aneurysmal Bone Cyst: its Roentgen Diagnosis. Radiology, $68,54$.

TAYLOR, F. W. (1956): Aneurysmal Bone Cyst. Journal of Bone and Joint Surgery, 38-B, 293.

Thompson, P. C. (1954): Subperiosteal Giant-Cell Tumor. Journal of Bone and Joint Surgery, 36-A, 281.

VOL. $50 \mathrm{~B}$, NO. 1, FEBRUARY 1968 